\title{
Reinventing Hybridity in a Globalized Context: The Case of Turkish Soap Operas and Their Reception in Morocco
}

\author{
OUAFAA RAFI \\ Sciences Po Paris, France \\ ORCID No: 0000-0002-1923-2851
}

ABSTRACT This article aims to examine Turkish soap operas as a multi-faceted phenomenon that, as a product of cultural hybridization, will also contribute to similar cultural hybridization in the countries and regions where they are broadcasted. The purpose is to highlight the fact that this is not a unilateral process of cultural influence, with an active production pole and a static and non-active receptor, but rather a dialectical process of hybridization, transformation, and adaptation. Analyzing the power of television and the strategies used by soap operas to attract an audience, the article highlights the dynamics accompanying their diffusion and the impact on the watchers. The main conclusion of this work is that Turkish soap operas are at the same time an outcome of cultural hybridization and a vector of this phenomenon since the series will influence the cultural frame of references of their host societies. The case study on Morocco helps us understand the encompassing dynamics at stake when it comes to cultural influence and interaction.

Keywords: Turkish Soap Operas, Morocco, Cultural Hybridization 


\title{
Introduction
}

\begin{abstract}
or more than 5 years, the story of Manar and Kamal, the main characters of the Turkish soap opera ${ }^{1}$ Samhini (Beni Affet in Turkish) kept more than 4 million Moroccan spectators ${ }^{2}$ on the edge of their seats every evening. Dubbed into Darija, a Moroccan dialect of Arabic, the soap opera with its numerous twists and vagaries, and its endless intrigues, became the archetypal image of Turkish soap operas for Moroccans.
\end{abstract}

Turkish Soap operas are the cultural illustration of hybridization as they show how the western conception of television programs can be transformed by non-dominant cultural actors and reflect an ambiguity because of a double cultural allegiance. Hence, Turkish soap operas are based on a common universal ground of soap operas, which are meant to be melodramatic, with unlimited episodes and seasons and unpredictable regarding the twists of the intrigue. However, they can be distinguished from Western soap operas since on the one hand, they are targeting a specific audience, with regionally specific cultural preferences. On the other hand, Turkish soap operas are a symbol of the desire of differentiation in the context of a fear of a cultural homogenization with western cultural products. The success of Turkish soap operas in Morocco can therefore be explained by this dual process of adaptation and by the perceived cultural and religious proximity with Turkey that cannot be felt with Western cultural products.

\section{Turkish soap operas are a symbol of the desire of differentiation in the context of a fear of a cultural homogenization with western cultural products}

Moreover, it is important to note that Morocco was never a part of the Ottoman Empire, unlike other countries in the Maghreb region such as Tunisia or Algeria. Hence, in Morocco, the Turkish cultural influence will be perceived as less threatening and more accepted than in the case of historical records of political domination over the latter countries.

In Morocco, the two main TV channels, $2 \mathrm{M}$ and Al Aoula, broadcast Turkish soap operas that have gradually become a social phenomenon accompanied by social reverberations, notably with the growing idealization of and fascination for Turkey in the Moroccan society, particularly among women and popular classes. The seductiveness of the Turkish cultural in-betweenness, between Europe and the Islamic World, transmitted by the soap operas, is the ultimate symbol of their pervasiveness as a vector of the Turkish model, or the "Turkish way of life."

This increasing idolization of Turkey also has economic consequences, not only the growing importance of Turkish fashion brands in Morocco, but also 
the increasing popularity of Turkey as a touristic destination, especially since the establishment of the visa-free policy for Moroccan citizens in 2007.

The relationship between the popularization of Turkish soap operas and the improving perception and image of Turkey in the Arab world can be seen in the results of a survey conducted in Arab countries. According to this research, 78 percent of the participants stated that they had a positive image of Turkey, and 74 percent admitted to having watched Turkish soap operas. ${ }^{3}$

The present article is based on the quantitative findings ${ }^{4}$ that the Arab public opinion is generally favorable to Turkish soap operas and Turkey in general and will illustrate how Turkish soap operas are perceived by their Arab viewers. This will be done through interviews with ten Moroccan women, whose names will be kept anonymous, from various backgrounds and ranging in age from 19 to 73. These interviews aim to enrich and broaden the perspectives surrounding the reception of Turkish soap operas in Morocco. Only one simple question was asked to the interviewees: "Do you watch Turkish soap operas, and why?" We believe asking this simple question enabled us to have clear answers from the participants regarding their motives of watching Turkish soap operas which in turn helped us understand their perceptions of Turkey. Some of the answers are quoted, whereas others were simply used as a guideline for propelling the analysis of trends.

We have also interviewed two experts Jana Jabbour, Ph.D. in political science and international relations from Sciences Po Paris, professor and researcher at Sciences Po Paris and at the Saint Joseph University of Beirut, and Aghiad Ghanem, Ph.D. candidate and researcher at Sciences Po Paris.

Before going into the details of the dynamics of Turkish soap operas as revealing and creating processes of hybridization, the article will first discuss the power of television in the context of cultural globalization, focusing primarily on the reception of soap operas and their impact on the audience. The second part will be centered on the notion of cultural ambiguity and the mechanisms of hybridization. The final part will concern the diplomatic and state use of soap operas as a provider of cultural influence in the MENA region, and particularly in Morocco.

\section{The Social Power of Television in a Context of Cultural Globalization}

Watching television is a ritualistic act, especially when it comes to watching a program that is broad casted at a given time in a regular manner, and Turkish TV series offer a frame of repeated interaction between a program and its viewers. Hence, according to Talcott Parsons' definition, ${ }^{5}$ they can be seen as a form 


\section{The infatuation of Moroccans with Turkish soap operas is spread and reproduced through newspapers}

lower-and middle-class people in Morocco. A woman of 43 years old, belonging to the middle class, interviewed in the frame of this research, stated that she regularly watched soap operas in order to escape reality. Soap operas have almost a cathartic value for her, since by watching them she is able to exteriorize her dreams: "the houses of the characters are beautiful, they have fancy clothes and a life that I would be jealous of."

The selection of themes is another facet of the production and marketing strategy of Turkish soap operas. Many developments throughout the episodes concern the recurring themes of love affairs, revenge, and honor, all of which are among taboo themes in the MENA region. Taboos, when tackled, have the ability to create discomfort since they are untouched subjects. Taboos can represent the emanation of social norms enforcing a control on individual and collective behaviors, limiting their free will and indexing their behaviors on what is morally and socially acceptable. In Morocco, taboo is described by the word hchouma, which can be translated by shame or disgrace, and is understood as a social norm that has a restraining effect on the society, which means that Moroccon society can be described as one with an important social control. According to Vézina and Paul, ${ }^{8}$ social taboos can be used as a deliberately provocative strategy in advertising. In the MENA region taboos are thus infused into soap operas to attract more audience. For example, Al Achq al Mamnou (Aşk-ı Memnu in Turkish) tells the fanciful story of a young woman marrying a rich older man and falling in love with his handsome nephew. This soap opera exemplifies all the characteristics mentioned above, by showcasing not only the wealthy and opulent life of a rich Turkish family with a variety of luxurious houses, cars, and dresses, but also the taboo of a politically incorrect story of adultery in which the man is betrayed by his wife, leaving his masculinity and honor hurt.

Moreover, we can talk about the rhizomatic ${ }^{9}$ nature of the soap operas. As coined by Deleuze and Guattari ${ }^{10}$, this term refers to a permanently evolving structure without center Hence, the rhizomatic power of the series resides in their non-circumscription by their inherent duration. Indeed, the power of a TV series is not limited to the length of its episodes, but they can operate beyond these limits and interfere in many facets of the viewer's daily lives. As Barker points out, the "soap talk," around the soap opera and its themes, enabling the viewers to contextualize the soap opera into tangible situations by placing the fictional context of the soap opera into the reality of everyday life. 
Turkish soap operas are embedded in the frame of a standardized format of cultural production shared by western soap operas. However, at the same time, they are an expression of the diversity and difference of the peculiar culture in which they were created, fulfilling the need of more appropriate televisual paradigms to coincide with their norms and values
In Morocco, the "soap talk" around Turkish series is primarily centered on the intrigues, recent developments, and twists in the story. The suspense created at each episode's ending ties the audience to the soap opera by keeping them on their toes. Hence, the question, "What happened again in Samhini?" has become popular caricaturized sentence in Morocco making it a perfect conversation starter. Discussions on the soap opera, which also concern other topics such as the portrayed Turkish way of life, the physical appearance of the characters, and even gossip related to the real lives of the actors and actresses, are conducted in the social media as

well. Since Turkish soap operas, contrary to the Latin American telenovelas, came out in the era of increasing technologies of communication, they are firmly embedded in the new media and social networks. In Morocco, where there are more than 16 million active users of Facebook and more than 4 million users of Instagram, ${ }^{12}$ more than 40 Facebook pages ${ }^{13}$ dedicated to the series Samhini were identified, totaling an audience with more than one million likes. On Instagram, in July 2019, there were nearly fifty thousand posts with the hashtag \#Samhini. We can also note the use of numerous memes, which can be defined as a recognizable cultural element produced and reproduced on a large scale and shared by the means of social media, based on Turkish soap operas as a means of propagation of their universe beyond the frame of television. As the use of social networks increase, especially amongst the young, these memes can be about many subjects in everyday life of Moroccans.

The infatuation of Moroccans with Turkish soap operas is spread and reproduced through newspapers. Many Moroccan newspapers have published at least one article about Turkish soap operas, ${ }^{14}$ describing them either as a social phenomenon or as a national obsession. These articles underline the preponderant nature of the "soap talk" as a socializing and communalizing feature of interpersonal relationships in Morocco. Indeed, the "soap talk" will allow viewers to have a reflexive approach in their social behaviors since as Giddens ${ }^{15}$ defines, its reflexivity enables the individual to revise their social activity in the light of new knowledge. There is hence a dialectical approach, with the information and knowledge received from the Turkish series, and the actual behaviors impacted by this new knowledge. As an illustration, Gubash ${ }^{16}$ notes 
that Muhannad, the main character in Al Achq al Mamnou, "has become the standard against which Arab men are being judged." The admiration, sometimes deification, of celebrities is not a new trend and has been widely observed throughout the years, notably by Morin, ${ }^{17}$ who observes the conjunction of mythification and deification of the stars that exercises a presence on the admirers' lives notably by their picturized presence.

Furthermore, as emphasized by Brown ${ }^{18}$ and Yalkin and Veer ${ }^{19}$, women's conversations on soap operas can be considered as a form of resistance. Women's "soap talk" in Morocco can be archetypal of this trend since Moroccan society is highly normative, gridded by social injunctions, especially towards girls and women. The hchouma notion epitomizes this situation since it evokes a restraining power based on cultural and religious rules and constitutes a series of limitations and censor when it comes to taboos, mainly linked to sexuality. The discourse of many female viewers towards the handsomeness of some Turkish actors, such as the iconic Muhannad, can be seen as a form of resistance since they break the traditional gendered role of women. Likewise, "soap talk" enables and allows women to evoke taboo issues revealed in the series. Turkish soap operas can be described as liminal (Van Gennep) ${ }^{20}$ in-between, spaces where taboo issues are tolerated because of their subordination to the fictional environment related to the series. Therefore, teenagers or women in Morocco would talk more easily about premarital sex, rape or love when it is in relationship with the soap operas' frame of references. More broadly, television can be perceived as a liminal space, an in-between moral space enabling viewers to have more freedom in tackling those very issues. Therefore, considering globalization as a dual process, in which there is an increase of mobility and a complexification of the imaginaries, is a consistent way to describe the intrinsic dynamics of TV and by extension soap operas in the Arab World.

Consequently, we can broaden our analysis with the concept of Media Event as developed by Katz and Dayan ${ }^{21}$ which describes the interconnection and conjunction of a plurality of separated spheres into a unique sphere of "the public" through a process of integration as the means to a "collective heartbeat." The concept of media event, primarily used to describe the process by which major breaking news development is forging a collective imaginary community, can also be applied in the case of broadcasting a TV series, especially when they are watched by a large audience and embedded into a new routine. ${ }^{22}$ Hence, both the diffusion of a new Turkish soap opera episode and the transmission of the last episode of the series can be perceived as a media event. In the case of the last episode of Samhini, broadcasted on the July 24, 2019 after 1727 episodes, the Huff Post Maroc ${ }^{23}$ talked about "the end of an era." The last episode is the quintessential iconic image of the pseudo-historical moment shared by the society thriving to know the climax of the soap opera that has been airing for years. 


\section{The Attractiveness of Cultural Ambiguity: Between Differences and Proximity}

Significantly, Turkish soap operas benefit from the cultural miscegenation they are based on. Indeed, Turkish soap operas are based on a cultural ambiguity, which is present on many levels. First, Turkish soap operas use the traditional soap opera frame of references but reconstruct them in a different manner by granting a peculiar Turkish note revealing the duality of globalization, as defined by Warnier. ${ }^{24}$ Indeed, instead of being a one-sided phenomenon, in which a dominant culture is broadcasted widely, globalization admits the existence of two equally dynamic poles, the production and reception. The cultural creations and products once received are not simply assimilated and diffused, but changed, modified and adapted. Warnier ${ }^{25}$ rejects the idea according to which globalization would directly lead to a standardization of the culture, as prophesized by Baudrillard. ${ }^{26}$ In fact, Baudrillard ${ }^{27}$ set an alarmist discourse in his approach describing the popular culture as based on a market-oriented rationale indexed to the consumption society leading to an Americanized uniformization. The Turkish soap operas, through their intrinsic differences with western soap operas, reveal the flaw of this thesis, especially with the creation of peculiar cultural products mixing "between the local and the hegemonic" that can be seen as a form of resistance, as underlined by Hall and Du Gay. ${ }^{28}$ The context of an overwhelming threat of cultural homogenization is therefore an important incentive for cultural production reactively emphasizing the singularities.

Hence, as Cornelius Castoriadis ${ }^{29}$ states, imagination is a factor of infinite cultural and social diversification. As illustrated by Turkish soap operas, the artistic creation and cultural production instrumentalize the mass consumption to create difference. Turkish soap operas are embedded in the frame of a standardized format of cultural production shared by western soap operas. However, at the same time, they are an expression of the diversity and difference of the peculiar culture in which they were created, fulfilling the need of more appropriate televisual paradigms to coincide with their norms and values. Turkish soap operas can thus epitomize the "glocal" concept as presented by Ritzer, ${ }^{30}$ since they are a mix between the local and the global creating an appropriation of standardized cultural references in order to produce something singular. This can be assimilated to a form of counter-reaction to homogenization, highlighting the reactivity of the cultural aggregates when they are threatened. Cultural production is therefore a "third-place," a term presented by Homi Bhabha, ${ }^{31}$ which initially designates the place in which the non-majoritarian aggregate is developing a strategy of mobilization of its particularisms, in order to highlight its differences with the majoritarian discourse.

All the aforementioned trends can be comprised in the frame of the larger phenomenon of Cultural Hybridization. As described notably by Homi Bhabha, ${ }^{32}$ 
the concept of hybridization reveals the dynamics of intertwinement, of dialectical encounters and of mutual enrichment between cultural blocs that occur in the frame of globalization. The labeling of a cultural bloc as hegemonic, or dominant, is henceforth minimized and undermined by the reality of the cultural projection of this very bloc since the receptor society will transform and readapt some of the facets of this cultural aggregate to make it more suitable for the local preferences and local values.

Therefore, Turkish soap operas are the reflection of cultural hybridization since they emanate from a standardized and westcan cannot be compared to soap operas from other regions. There is a common ground shared by the soap operas in general, based on an affirmed melodrama, on plots and intrigues punctuated by pathos and tragedy, and with an emphasized suspense at the end of each episode. However, the Turkish series consider local preferences by emphasizing stories related to social values such as honor, to the schism and duality between rich and poor, and to themes like revenge. More importantly, the scenes are more respectful of the values and norms of eastern society, with less sex scenes and a greater emphasis on social values. "Umutsuz Ev Kadinlarl," which is the Turkish version of the American soap opera "Desperate Housewives" was created in 2011 and it significantly illustrates this point since it is the archetype of the adaptation to local sensibilities.

Indeed, there are less sex scenes and the narrative spine is purged from controversial elements, such as homosexuality and lesbianism, alcoholism, or pregnancy out of wedlock, that punctuated the original plot. The universe of the original soap opera is preserved, enabling it to have emancipated modern female characters, living in rich houses and wearing beautiful clothes, however, all the elements that could outrage the audience are suppressed. In terms of form, the length of episodes is symptomatic of this appropriation of the series' codes catering to the preferences of the MENA audience, which prefers longer episodes and considers the viewing of the episode as an occasion of evening leisure. In Morocco, where the working day usually ends at 4:00 p.m. in the public sector and around 6:30 p.m. in the private sector, the broadcasting of Turkish soap operas such as "Samhini" is strategically placed at 7:25 in the evening, ensuring the presence of a large audience. Additionally, series are not subjected to seasonal limitations and are uncurbed by episodes considerations. It is therefore common to have a Turkish series with more than 1,500 episodes; 


\section{Turkish soap operas} are contributing to the creation of a shared imaginary in the Muslim world linked to their massive broadcasting with at least one broadcasted every day, which binds the audience even more since watching the series is now part of a daily routine.

Thus, the Turkish soap operas are based on the emphasis of a highlighted regional cultural specificity. This trend, as described by Appadurai, ${ }^{33}$ is significant since it proves the growing region-specific character of the cultural domination, which means a strategic redeployment of culture aggregates in order to operate a region-oriented cultural projection. For Appadurai, ${ }^{34}$ the mediascapes are the aggregates of imagery products such as TV series, videos, and images, that are intrinsically connected and contributing to global cultural flows. The case of Turkish dramas is archetypal of mediascapes since they are embedded in a global system of flows but at the same time, they are fostering a regional specificity.

On the same note, Turkish soap operas are using their position as a cultural in-between, amongst Europe and the Middle East. This kind of ambiguity is particularly attractive for the Arab audience. For instance, one of the Moroccan women interviewed (46 years old, lower class) said: "I watch Turkish soap operas because they make me dream, the actors, the landscapes, everything is beautiful. Turkey is like Europe, but they are Muslims, so it gives me hope that one day we could be like them." Therefore, this aspect adds more value to Turkish soap operas, since in addition to providing a leisure time for viewers, they provide them with an opportunity for escapism into another reality. Moreover, we could present a hypothesis linking the increasing popularity of Turkish soap operas to the uprising of the Arab spring. Indeed, with the increase in violence and conflicts, Turkish soap operas can be considered as outlets enabling a diversion from the actuality, particularly in Morocco, where there was a fear of unrest and contamination from the neighboring countries.

Additionally, the attractiveness of Turkish soap operas is increased because of this perceived cultural proximity, which is not shared for instance with Latin American telenovelas. This thematic cultural familiarity reveals the intrinsic tendencies linked to the consumer's choices. Indeed, as shown by Yüksel Köksal and Nihal İçöz Gjana ${ }^{35}$ the numerous works (Crawford \& Lamb, 1981; Wang \& Lamb, 1983; Watson \& Wright, 1999) analyzing consumer choices observed a preference for productions emanating from a country that shares some cultural aspects with the country of the consumer. As examined by Köksal and İçöz Gjana (2015), "the country of origin image (COI) consists of views and beliefs a person may hold about a specific country." The choice of watching a Turkish series will hence not only be influenced by the quality of the plot and series per se, but also by their "Turkish-ness" or Middle Eastern regional and cultural nature. 


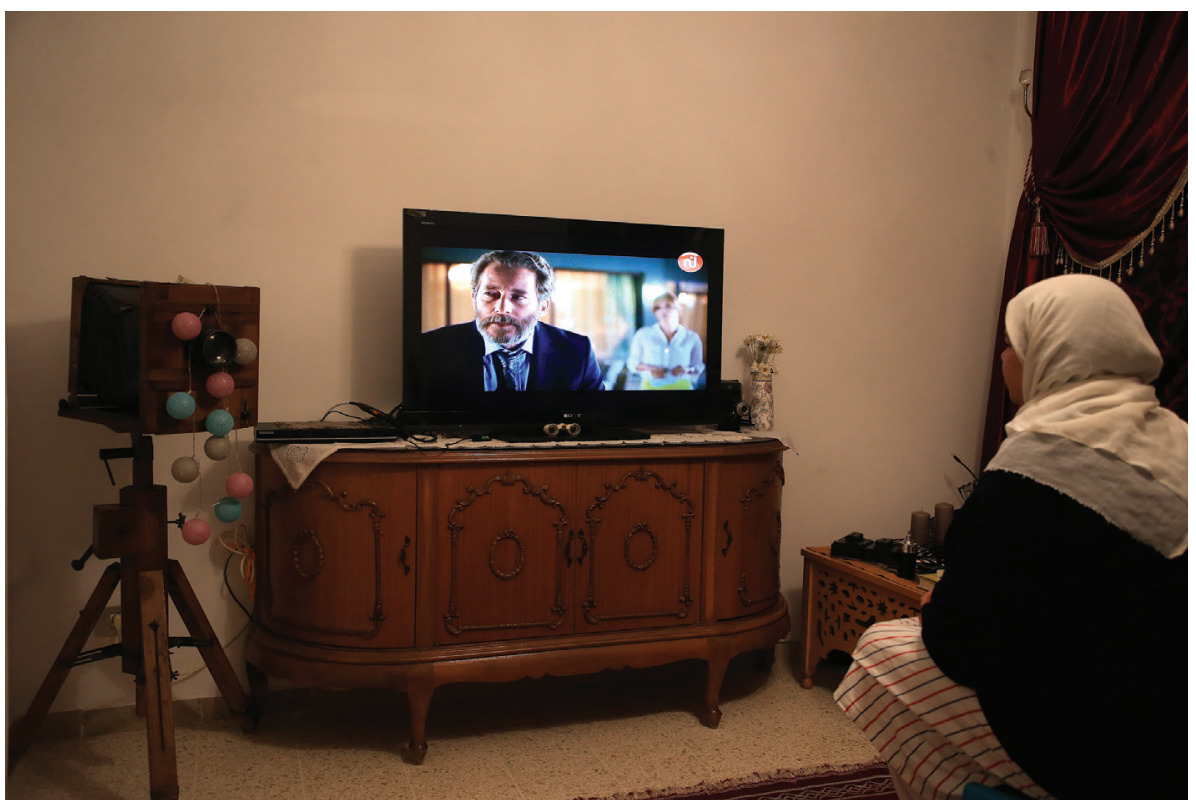

Turkish series continue to dominate television screens, appealing to the tastes of Tunisians for the last 10 years. Television channels in Tunisia compete with each other to broadcast Turkish TV.

The branding "Turkish" of a soap opera will influence and impact on the decision of the viewers, as consumers tend to pay attention to the origin to assess the quality of the production. This aspect poses the question of the subjective views and beliefs a person has about a country. These views can be false or biased, but the consequences of these views will be real as they will impact the choices of the person, which leads to a form of consequentialism, as presented by the work of Berger and Luckmann. ${ }^{36}$

Nevertheless, what needs to be underlined is that Turkish soap operas are also subjected to hybridization in the countries and regions into which they are diffused. Indeed, in Morocco, soap operas are translated into the Moroccan dialect Darija, and not into literary Arabic. Additionally, the titles of the series are changed, and the names of the characters are replaced by Arab names popular in Morocco such as Manar, Kamal or Farida. ${ }^{37}$

Turkish soap operas represent a nexus between modernity and respect of the religious principles. However, this variable, according to which Turkish series represent a proof that Islam can be conciliated with modern life, is biased as in Morocco the viewers are given a transformed version of the soap operas. They are not watching the original version, but a highly censored one, with scenes representing sexual relations, drinking, or even a simple kiss on the lips censored by the two main channels. Even if the Turkish soap operas are described as less indecent or sexually inappropriate than western equivalents, ${ }^{38}$ they also 
This increasing idolization of Turkey also has economic consequences, not only the growing importance of Turkish fashion brands in Morocco, but also the increasing popularity of Turkey as a touristic destination, especially since the establishment of the visa-free policy for Moroccan citizens in 2007 are subjected to censor which is justified by the necessity to readapt the televisual content to the sensibilities of the local audiences. However, the censor can easily be sidelined by watching the subtitled original versions of the series on streaming, a method which has become increasingly popular in Morocco.

Moreover, the local appropriation of the universe of the soap operas in Morocco can also be illustrated by the growing interiorization of codes and norms related to the series, which are coupled with an increasing fascination of all the Turkey-related products, trends, and elements. Indeed, far from being simply a trivial consideration, the physical appearance of the actors is significant in the articulation of the cultural ambiguity. In fact, the European appearance of the actors, with light colored eyes and at times blond hair, is important since they reflect this dual identity of Turkey, depicted as being at the crossroads of Europe and the Middle East. The collective definition of standards and beauty will be impacted in the circles of Turkey aficionados with Muhannad for instance, described as the Halal Brad Pitt, who has gradually become a sex symbol. In addition, particularly among young women, the shifting standards of beauty and the influence of the Turkish beauty icons such as Manar, ${ }^{39}$ star of Samhini, or Lamiss, ${ }^{40}$ who became a Pantene ambassador in the Middle East, will have a clear impact on the aesthetic preferences of young women and tend to favor mimicry tendencies. When Homi Bhabha ${ }^{41}$ talks about mimicry, he refers to the ambition and efforts of a dominated actor to resemble the dominant actor, erected as a model, by adopting their behaviors. The propagation of images through Instagram or Facebook for instance will have an impact on the individual and collective desires and will provoke a shift in their image aspirations. Joseph Tonda refers to this shift as "société des éblouissements," 42 which can be translated as the "shine society," enacted through the over-mediatization of images and mediascapes interfering in the daily life of the individuals. However, what needs to be underlined is that in Morocco, there is a clear feeling of not belonging to Africa, and a rejection of "African-ness," observed by Corbin Treacy. ${ }^{43}$ The work of Frantz Fanon, ${ }^{44}$ and particularly his influential book Black Skins, White Masks effectively explains this trend. Indeed, Fanon ${ }^{45}$ describes the interiorized feelings of inferiority of colonized people and their inherent desire to elevate their status to that of white people. This rhetoric can be applied to Moroccans since they tend to consider themselves as superior to Black sub-Saharan populations, as the 
bridge to Europe and as having an intermediate status between white and black people. The apparent desire to look like Turkish actors and actresses can hence be seen as the figurehead of the wish to look European.

\section{Branding the State: The Middle-Sized Power Privilege}

The soap operas' influence encompasses the cultural and social spheres in Morocco, and their rhizomatic effect is an undeniable power that can be absorbed by the state in the act of fulfilling state interests. We must put the state use of soap operas in the frame of the shifts in and reconfiguration of its foreign policy recently conducted by Turkey. Indeed, there is a double shift in Turkey's foreign policy, which has become more visible since 2009. On the one hand, according to Tutal-Cheviron and Çam, ${ }^{46}$ under the leadership of the JDP (Justice and Development Party-the Ak Parti in Turkish) and with Ahmet Davutoğlu as minister of foreign affairs, Turkey abandoned its Kemalist foreign policy, which was centered on Europe and the U.S., to reinforce its economic, political and cultural relations with countries of the MENA zone. On the other hand, according to Yalkin and Veer ${ }^{47}$ there has been a shift from the idea of pan-Ottomanism, promoting a revivification of Turkish influence and power on the regions previously under the control of the Ottoman Empire, to a more harmless position. Indeed, this pan-Ottoman policy was based on a perceived Turkish superiority over the Arab countries that led to a paternalistic approach of foreign policy and to a tutelage relationship in which Turkey was propelling the creation of a cultural and economic sphere of influence modeled on the Ottoman possessions. Hence, Turkey started to be presented less as a previous colonial Ottoman power but more as a post-colonial power aiming to become the spokesperson of the Global South, particularly in the Muslim World, as seen with the then Prime Minister Erdoğan's proactivity in what concerns the Palestinian cause, epitomized by the Davos "one minute" incident in 2009.

The strategy of rebranding the Turkish foreign policy is embedded in a broader project of rebranding the state, which is hoped to lead to a greater receptivity of Turkish influence by Arab countries. Indeed, as underlined by Van Ham, ${ }^{48}$ State Branding is comprised of "the outside world's ideas about a particular country" and is based on a constant differentiation of a state from others. The JDP-propelled Turkish State Brand is the one that will underline the reconnection of Turkey to its Middle Eastern and Muslim environment by promoting a cultural return to the roots of their internal spheres, and a policy of cultural cooperation amongst Muslim countries.

Moreover, Aghiad Ghanem interviewed in the context of this article, states that emerging powers are undeniably linked to the concept of recognition, 
and can use two main weapons to fulfill this goal: rebellion, which is contesting the existing norms, and innovation, that constitutes the will to propose other alternative norms and paradigms, as cultural products. The Turkish strategy is a unique conjunction of these two strategies, since there is an undoubtable will to provide a unique and personal narrative for the Muslim world, which can be perceived as a counter-hegemonic activity. ${ }^{49}$ Likewise, it is important to note that Turkish soap operas are contributing to the creation of a shared imaginary in the Muslim world linked to their massive broadcasting. Ghanem also asserts that the value of culture in the post-Westphalian era is dual, since on the one hand the interests of state-actors are multiform and can be political as well as social and cultural, while on the other hand, the number of actors in the world is now in a constant increase, with the state-actors no longer dominating the cultural sphere. Hence, the strategies of the states will be influenced by this bifurcation of international relations $s^{50}$ by which state-centered international relations cohabitate with a multi-centric world.

The facets of this new repositioning of the Turkish foreign policy is the establishment of an enhanced cooperation with MENA countries, based on a logic of civilizational politics and described as post-Ottomanism by Jana Jabbour, a researcher and professor at Sciences Po Paris that was interviewed for this article. This diplomatic trend is exemplified notably by the increasing Turkish investments in MENA countries, and by the will to launch regional economic alliances. For instance, in 2010, the project of a Şamgen zone, a free trade area between Turkey and the countries of the Levant, was presented by the Turkish government as a way to favor regional economic alliances following the model of the Schengen space.

On another level, cultural production and by extension Turkish soap operas are under the domain of influence and action of the state that considers them as a facet of the cultural diplomacy. Indeed, as emphasized by Dumont, ${ }^{51} \mathrm{cul}$ tural diplomacy is the specific use of cultural relations as a tool for the realization of economic, commercial, and political goals in the foreign relations of the state. In this frame, the process of instrumentalization of the production of cultural products by the state takes place in order to assess the congruence between state and cultural production. The governmental institution in charge of surveillance of the audio-visual productions, RTÜK (Supreme Council of Radio and Television), monitors the content of the soap operas and insists on the importance of the conformity between the depiction of the society by the soap operas and the Turkish model as transmitted by the official narrative. The JDP government financial aid to Turkish series promoting certain traditional family values is symptomatic of this trend. Moreover, according to Jana Jabbour, there is a dual process of censorship of Turkish soap operas: an upstream process of preventive auto censor made by TV producers that makes sure not 
to tackle sensitive issues and a downstream censor that sometimes leads to the ostracization of series. Hence, the Turkish state is ensuring that it has cultural productions coinciding with the image of Turkey they wish to promote which thereby help the realization of their objectives outside their national borders, even if state-control on cultural production may be complex and difficult. ${ }^{52}$ Therefore, in addition to being mediascapes, the Turkish soap operas are diffusing ideoscapes ${ }^{53}$ that are the flows of ideas, understanding and perceptions that are embedded in a system of global connections.

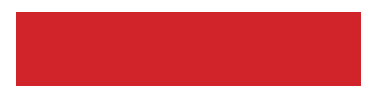

\section{The Turkish state is ensuring that it has cultural productions coinciding with the image of Turkey}

Because of this trend, there has been a process of "forced politicization of the Turkish soap operas celebrities." ${ }^{4}$ Indeed, as Turkish soap operas are increasingly considered as representative of Turkey in the world, the actors are considered as Turkish ambassadors that need to be irreproachable. The actors that do not respect the state-led policy could be subject to a vigorous name and shame by Turkish society, as happened with Mehmet Ali Alabora, who participated in the Gezi Park protests in 2013.

Thus, we have a case in which cultural relations are constituted of elements and flows that are not necessarily emanating from the state but that are absorbed by the state to enter the domain of the exclusive state prerogative of cultural diplomacy, serving state interests in the foreign spheres. Therefore, private actors such as TV producers, contribute to aims and objectives that are the same as those of state's foreign policies. The cultural influence and cultural power of Turkish soap operas tend to be the embodiment of the strong amplitude of projection characterizing the soft power, through which a state intends to achieve strategic, economic and political goals using intangible assets such as cultural products.

As emphasized by Bertrand Badie ${ }^{55}$ soft power is a double-edged sword, since the overwhelming presence of a state's culture can be subjected to suspicion and seen as a threat. However, the Turkish cultural influence in Morocco is relatively accepted in Morocco and multiple factors could explain this. First and foremost, Morocco, contrary to other North African states, has never been under the control of the Ottoman Empirethe. This historical fact diminishes the threat perception and obliterates the potential siege mentality that can be present in the collective imaginary of former Ottoman provinces. Moreover, the reception of Turkish cultural products in Morocco is not accompanied with a fear of Turkish hegemony and invasion of the national territory, as it is the case for Western cultural soft power. Indeed, Turkey is perceived as a benign power and seems to be a cultural insider sharing an Islamic and Middle-East- 


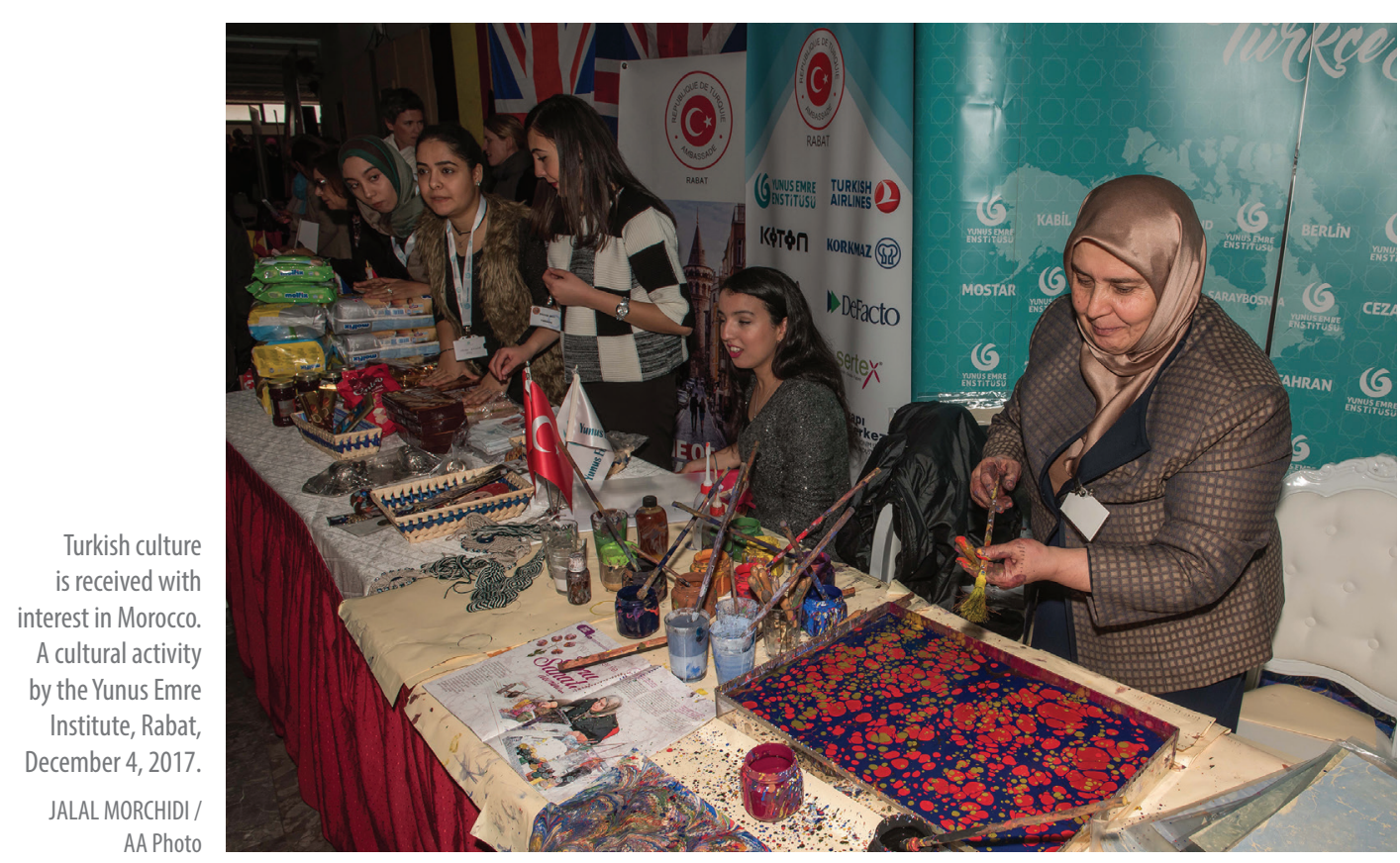

ern religious and cultural heritage. As underlined by Jana Jabbour, ${ }^{56}$ Turkey is perceived as a regional power whose potency is not threatening and which is not aiming at interfering in the internal affairs or at imposing its domination on a given country. Thus, it seems clear that Turkey benefits from what can be called a middle-sized power privilege since its power does not seem as menacing as the western superpowers.

Moreover, according to Aghiad Ghanem, we can consider the MENA zone and particularly the Muslim World as a field ("champ"), which means in the Bourdieu $^{57}$ terminology a space in which a competition is structured around specific stakes, a field in which there is a competition between not only the state-actors, but also the cultural and religious actors, to take on leadership in this world.

This conjunction of cultural proximity and of middle-sized power makes it easier for Turkey to penetrate countries such as Morocco, and to transmit its soft power through the medium of Turkish soap operas without being undermined by a potential suspicion of the audience, as in the case of western cultural products. While more than $4000 \mathrm{~km}$ separate Morocco and Turkey, the large diffusion of Turkish soap operas has created a tangible and perceptible feeling of closeness between the two countries, largely due to a perceived cultural proximity. 
The Moroccan attraction to the Turkish way of life, going beyond soap operas will be present in fashion. Turkish fashion shows the perceived cultural in-betweenness of Turkey. Indeed, the Turkish fashion brands reflect an imaginary that is exploited in the soap operas and that refers to the capacity of being at the same time modern and traditional. Since 2010, many Turkish ready-to-wear brands have been introduced into Morocco, benefiting from the middle-classes increasing purchasing power. Tekbir, for instance, proposes a vast offer of modernized modest clothing for women and is extremely popular in Morocco where they are seen as offering an alternative to the traditional djellaba for veiled women. One of the respondents said:58 "When I see Turkish soap operas, veiled women look elegant with their clothes that are at the same time modest and modern. I buy clothes from Turkish brands because they enable me to be classy without disrespecting my faith." Other brands have an enlarged market segment orientation and offer clothes for men, women and children. LC Waikiki has become one of the most important Turkish fashion brands in Morocco since their first shop opened in 2012, and they had opened 22 stores in Morocco by 2018, with a strategy of increasing the market shares, illustrated by the 10 million euros ${ }^{59}$ recapitalization of the Moroccan subsidiary in 2018. Another factor in the popularity of Turkish fashion brands is their undeniable competitiveness in terms of price, since they offer better value compared to other ready-to-wear brands such as H\&M or Zara, but also a greater quality than the clothes imported from China, sold in souks or in shops in popular areas.

Moreover, we should analyze the impact of Turkish soap operas on tourism. Indeed, as they present an overview of the landscapes in Turkey, they contribute to the attractiveness of Turkey as a touristic destination and tour operators sometimes include the visit of filming locations of famous Turkish soap operas such as Noor ${ }^{60}$ or Hareem el Sultan ${ }^{61}$ in their schedule. The visa requirements for Moroccan citizens, lifted in 2007, created an increased interest in Turkey as a touristic destination. In addition, the Yunus Emre Turkish Cultural Center in Rabat, founded in 2012, attracts hundreds of students to learn Turkish and potentially study at Turkish universities.

Hence, it can be said that Turkish soap operas have impacts in a large array of domains through an apparent cumulative trickledown effect so that they are going beyond their initial levels of broadcasting and reception by the audience. 


\section{Conclusion}

This article has found many dynamics underlying the diffusion of soap operas and their reception encompassing between the social and the political, between the private and public spheres.

The multi-faceted process of hybridization, happening dually in the phases of production and reception of cultural products, is accompanied by a plethora of reverberations attaining to social and economic levels and impacting into the daily lives of the viewers. As a result of this rhizomatic effect, the power of soap operas has been increasingly under the observation of the state, which found in soap operas the opportunity to reframe its soft power and reassess its geopolitical influence in the region.

However, it needs to be underlined that in Morocco, the increasing influence of Turkish dramas recently created a demand for cultural autonomy, based on the local production of television series in order to be liberated from an influence that has gradually become to be seen as invading. Indeed, the long-lasting nature and the dominance of Turkish series in the Moroccan channels has created a desire to have a Moroccan series inspired by the Turkish soap operas but implementing a unique Moroccan tone to which only the home audience can relate.

Among Moroccan producers, there is a common feeling of being able to produce local dramas that are comparable in their quality and plot to Turkish dramas. Therefore, Turkish soap operas were a great help during the phase of learning, but now there must be room to produce Moroccan dramas, whose success is linked to a desire to recover cultural sovereignty. ${ }^{62}$

Moreover, in 2014, the Moroccan minister of Communication, Mustapha Khalfi, said that he was envisioning the complete proscription of translated Turkish and Mexican TV series as they represented a threat to the Moroccan values and cultural production. ${ }^{63}$

Hence, the recent series produced in Morocco, such as "Sir el Marjane" (the Coral's secret), are inspired by the strategies of adaptation and adjustment that were applied by Turkish producers when they were recreating soap operas under the Turkish model. Therefore, we can argue that Moroccan soap operas are reproductions of reproductions since they tend to reproduce the Turkish model, instead of basing the production on the initial European model.

\section{Endnotes}

1. The terms Soap operas, dramas, and series are used interchangeably in this article.

2. Siham Jadraoui, “Audience TV: «Samhini» Cartonne Toujours," Aujourdhui, (August 02, 2018), retrieved from http://aujourdhui.ma/culture/audience-tv-samhini-cartonne-toujours. and http://www.ciaumed. 
ma/wp-content/uploads/2019/04/Ciaumed_Communiqu\%C3\%A9-de-presse-VF_-Semaine-du-03-au09-Avril-2019.pdf.

3. Paul Salem, "Turkey's Image in the Arab World," TESEV, (May 01, 2011), retrieved from https://www. tesev.org.tr/en/research/turkeys-image-in-the-arab-world/.

4. Salem, "Turkey's Image in the Arab World."

5. Talcott Parsons, The Social System, (London Glencoe III: Free Press, 1951).

6. "Communiqué de Presse Chiffres clés d'audience TV," CIAUMED, (2017), retrieved from http:// www.ciaumed.ma/wp-content/uploads/2018/03/Marocmetrie_Communiqu\%C3\%A9-de-presse_ Ann\%C3\%A9e-2017.pdf.

7. Chris Barker, "Television and the Reflexive Project of the Self: Soaps, Teenage Talk and Hybrid Identities," The British Journal of Sociology, Vol. 48, No. 4 (1997), pp. 611-628.

8. Vézina, Richard, and Olivia Paul, "Provocation in Adverstising: A Conceptualization and an Empirical Assessment," International Journal of Research in Marketing, Vol. 14, No. 2 (1997), pp. 177.

9. Rhizomatic as a structure in constant evolution, with no hierarchical structuration.

10. Gilles Deleuze and Félix Guattari, Mille Plateaux, (Paris: Edition de Minuit, 1980).

11. Chris Barker, "Television and the Reflexive Project of the Self: Soaps, Teenage Talk and Hybrid Identities," The British Journal of Sociology, Vol. 48, No. 4 (1997), pp. 611-628.

12. S.N, "Le Maroc Compte Environ 16 Millions D'utilisateurs Facebook," Medias, (May 24, 2018), retrieved from https://www.medias24.com/MAROC/TECH/183257-Le-Maroc-compte-environ-16-millions-d-utilisateurs-Facebook.html.

13. The four main Moroccan Facebook pages dedicated to Samhini, totalizing almost one million likes are: https://www.facebook.com/ssamhini2016/; https://www.facebook.com/SAMHINI2018/?ref=br_rs; https://www.facebook.com/Samhini2M/?ref=br_rs; https://www.facebook.com/samhinilaulau/?ref=br _rs; https://www.facebook.com/Samhini-2mbeni-affet-920644091297509/?ref=br_rs.

14. A non-exhaustive list of articles of Moroccan newspapers: https://www.h24info.ma/culture/television-top-5-series-plus-suivies-marocains/; https://www.lavieeco.com/societe/jamais-sans-ma-serieturque/; https://lematin.ma/journal/2008/Television_Ces-series-turques-qui-rendent-les-femmes-accros-/98514.html; http://fr.le360.ma/medias/interview-ain-el-haq-sur-2m-dans-les-coulisses-du-tournage-avec-le-realisateur-183422.

15. Anthony Giddens, Modernity and Self-Identity: Self and Society in the Late Modern Age, (Cambridge: Polity Press, 1991).

16. Charlene Gubash, "Soap Opera Upends Traditional Arab Gender Roles," NBC News, (July 31, 2008), retrieved from http://worldblog.msnbc.msn.com/archive/2008/07/31/1236952.aspx.

17. Edgar Morin, Les Stars, (Editions Seuil, 1957).

18. Mary Ellen Brown, Soap Opera and Women's Talk: The Pleasure of Resistance, (London: Sage, 1994).

19. Çağrı Yalkın and Ekant Veer, "Taboo on TV: Gender, Religion, and Sexual Taboos in Transnationally Marketed Turkish Soap Operas," Journal of Marketing Management, Vol. 34, No. 13- 4 (2018), pp. 11491171.

20. Van Gennep Arnold, Les Rites De Passage, (1909).

21. Daniel Dayan and Elihu Katz, Media Events: The Live Broadcasting of History, (London: Harvard University Press, 1992).

22. In Morocco, the episodes are broadcasted from Monday to Friday.

23. Abir El Adnani, “Vidéo. 2M: le Dernier épisode de «Samhini» la Fin d'une ère," h24info, (July 24, 2019), retrieved from https://www.h24info.ma/culture/video-2m-le-dernier-episode-de-samhini-la-fin-duneere/.

24. Jean-Pierre Warnier, La Mondialisation De La Culture, (Paris: La Découverte, 2017).

25. Warnier, La Mondialisation De La Culture. 
26. Jean Baudrillard, Le Système Des Objets, (Paris: Gallimard, 1968).

27. Jean Baudrillard, For a Critique of the Political Economy of the Sign, (St. Louis, MO: Telos Press Ltd., 1981).

28. Stuart Hall and Du Paul Gay, Questions of Cultural Identity, (London: Sage, 1996).

29. Cornelius Castoriadis, L'Institution Imaginaire De La Société, (Paris: Éditions du Seuil, 1999).

30. George Ritzer, The McDonaldization of Society, (London; Thousand Oaks; New Delhi: Pine Forge Press, 2004).

31. Homi K. Bhabha, The Location of Culture, (London: Routledge, 2004).

32. Bhabha, The Location of Culture.

33. Arjun Appadurai, Disjuncture and Difference in the Global Cultural Economy, (Public Culture, May 1, 1990).

34. Appadurai, Disjuncture and Difference in the Global Cultural Economy.

35. Yüksel Köksal and Nihal I. Gjana, "Soap Opera Effect on Product Preferences in Terms of Country Image: A Case of Turkish TV Serials in Albanian Market," Journal of Economic and Social Studies, Vol. 5, No. 1 (2015), p. 219.

36. Berger Peter Ludwig and Thomas Luckmann, The Social Construction of Reality: A Treatise in the Sociology of Knowledge, (Doubleday, Garden City, N.Y.C., 1966).

37. Names of the main characters of Samhini/ Beni Affet.

38. Dimitra Laurence Larochelle, "Brad Pitt Halal' and the Hybrid Woman: Gender Representations and Religion through Turkish Soap Operas," Essachess, Vol. 12, No. 24 (2019), pp. 61-78.

39. Gaye Turgut.

40. Tuba Büyüküstün.

41. Homi K Bhabha, The Location of Culture, (London: Routledge, 2004).

42. Joseph Tonda, L'Impérialisme Postcolonial: Critique De La Société Des Éblouissements, (Paris: Editions Karthala, 2015).

43. Corbin Treacy, “Reframing Race in the Maghreb," French Cultural Studies, Vol. 29, No. 1 (2018), pp. 1927.

44. Frantz Fanon and Charles L. Markmann, Black Skin, White Masks, (Grove Press, 1967).

45. Fanon and Markmann, Black Skin, White Masks.

46. Nilgün Tutal-Cheviron and Aydın Çam, “Chapitre 7. La Vision Turque Du «soft-Power» Et l'instrumentalisation De La Culture," Centre Jacques-Berque, (2017).

47. Yalkın and Veer "Taboo on TV," pp. 1149-1171.

48. Peter van Ham, "The Rise of the Brand State," Foreign Affairs, (2001), retrieved from https://www. foreignaffairs.com/articles/2001-09-01/rise-brand-state.

49. Marwan M. Kraidy and Omar Al-Ghazzi, "Neo-Ottoman Cool: Turkish Popular Culture in the Arab Public Sphere," Popular Communication, Vol. 11, No. 1 (2013), pp. 17-29.

50. James N. Rosenau, Turbulence in World Politics: A Theory of Change and Continuity, (Princeton N.J: Princeton University Press, 1990).

51. Juliette Dumont, "From Intellectual Cooperation to Cultural Diplomacy: The Course of Brazil in the Interwar Period," Caravelle, Vol. 99, (2012), pp. 217-238.

52. Joseph S. Nye, Soft Power: The Means to Success in World Politics, (New York: PublicAffairs, 2009).

53. Appadurai, Disjuncture and Difference in the Global Cultural Economy.

54. Ece Vitrinel, "Forced Politicization of Television Celebrities in Turkey," Journal of Balkan and Near Eastern Studies, Vol. 21, No. 2 (2019), pp. 222-233. 
55. Bertrand Badie, Quand Le Sud Réinvente Le Monde: Essai Sur La Puissance De La Faiblesse, (Paris: La Découverte, 2018).

56. Jana Jabbour, "Le Retour De La Turquie En Méditerranée: La «Profondeur Stratégique» Turque En Méditerranée Pré- Et Post-Printemps Arabe," Cahiers De La Méditerranée, (2014), pp. 45-56.

57. Pierre Bourdieu, Les Règles De l'Art: Genèse Et Structure Du Champ Littéraire, (Paris: Seuil, 1992).

58. Veiled woman of 47 years old, lower-middle class.

59. The exact amount in the Moroccan currency is 116 million of Moroccan dirhams. Source: Challenge. ma, (May 2018).

60. Gümüş.

61. Muhteşem Yüzyıl.

62. Catherine Miller, "Chapitre 12. Adapter et Produire Marocain: L'évolution des programmes de séries et films télévisés de la télévision Marocaine entre 2003 et 2012 ;" Dominique Marchetti, La Circulation des Productions Culturelles: Cinémas, Informations et Séries Télévisées Dans les Mondes Arabes et Musulmans, (Rabat, Istanbul: Centre Jacques-Berque, 2017).

63. Catherine Miller, "Chapitre 12. Adapter et Produire Marocain;" Marchetti, La Circulation Des Productions Culturelles. 


\section{SETA}

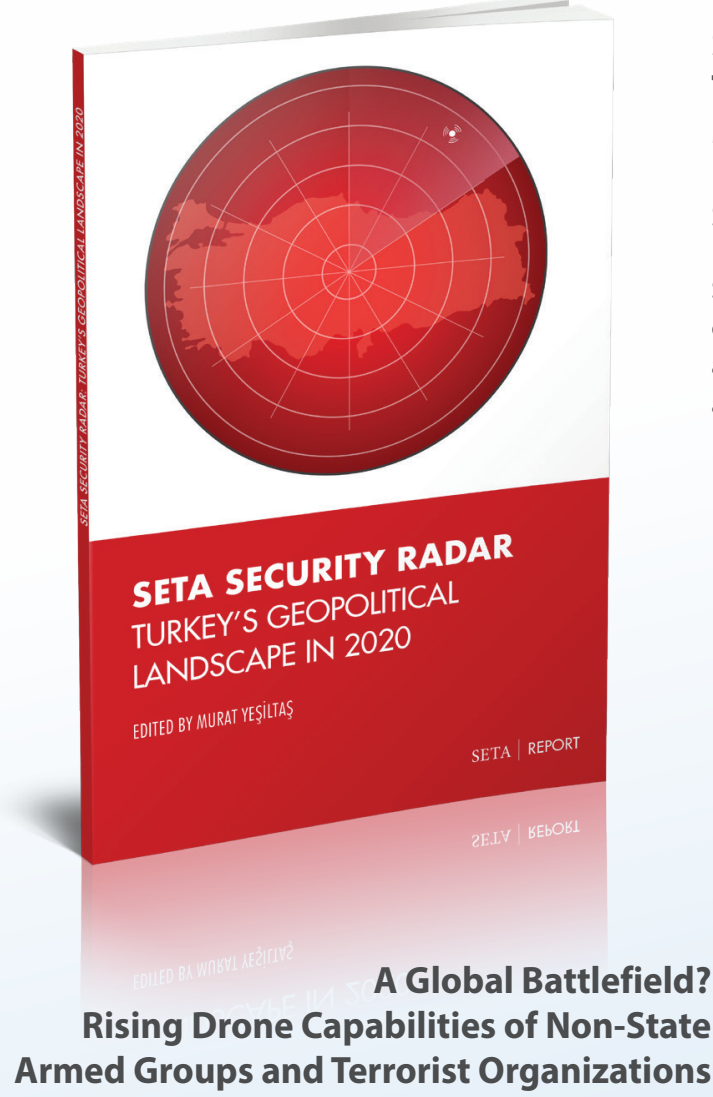

\section{SETA Security Radar |}

Turkey's Security Landscape in 2020

Murat Yeşiltaş, Murat Aslan, Bilgehan Öztürk,

Rıfat Öncel, Ümit Tetik, Ömer Özkizilcik,

Sibel Düz, Nur Günay

SETA Security Radar attempts to anticipate the course of major security issues Turkey faces and how to develop and enhance sound and relevant responses within this increasingly challenging regional security environment.

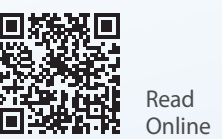

This study examines how terrorist organizations use UAV technology by learning from each other and analyzes their adaptation processes.

Online

A CLOBAL BATTLEFIELD?

A CLO CAPABLITIES OF NON-STATIZIZTIONS RISING DRONE CAPSD

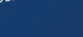

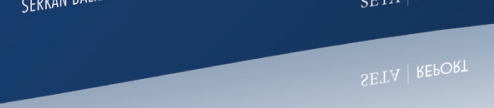




\section{SETA}

\section{Al-Quds | History, Religion and Politics}

September 2019| Abd al-Fattah EL-AWAISI, Muhittin ATAMAN

Considering the transformation process in the Middle East and the global transition, it is clear that the Palestinian-Israeli question and the issue of al-Quds will continue to dominate the agenda of the Middle East and global system. Recent regional developments such as Trump's decision regarding the future of Jerusalem and the solution proposal called the "Deal of Century" by the Trump Administration demonstrate that the holy city of al-Quds will continue.

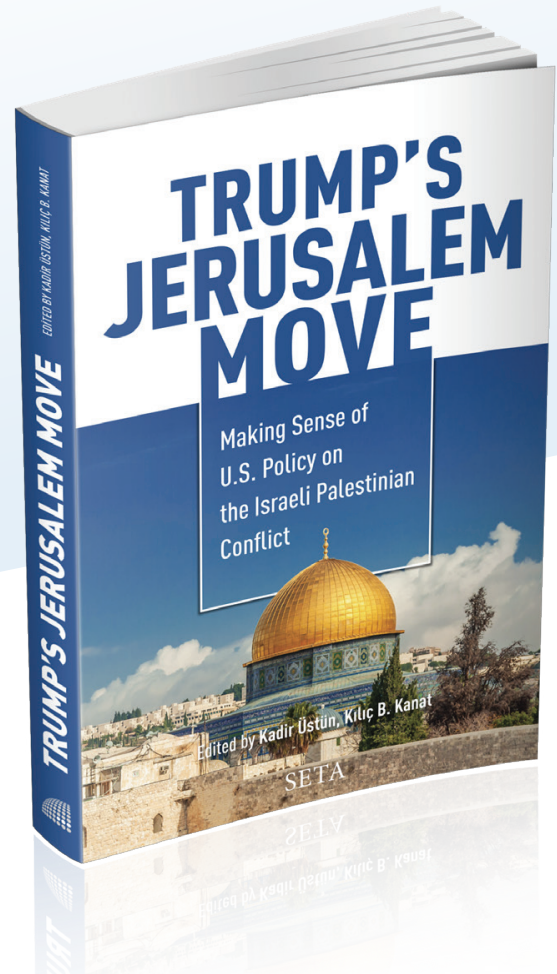

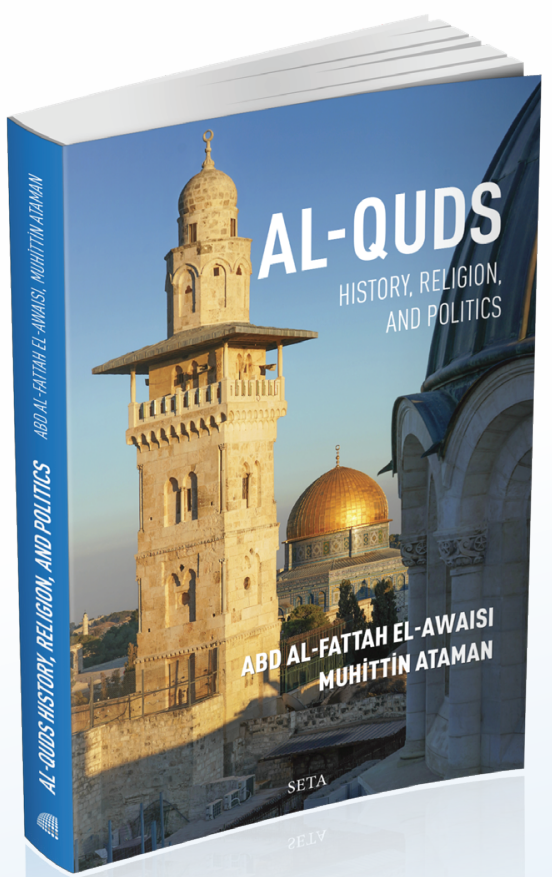

\section{Trump's Jerusalem Move}

April 2020 | Kadir Üstün, Kılıç Buğra Kanat

This critically important book includes chapters both contextualizing and discussing the U.S. administration's Jerusalem declaration in great detail. Various sections authored by American, Latin American, European, and Turkish authors examine the international responses to the U.S. President Trump's declaration. 

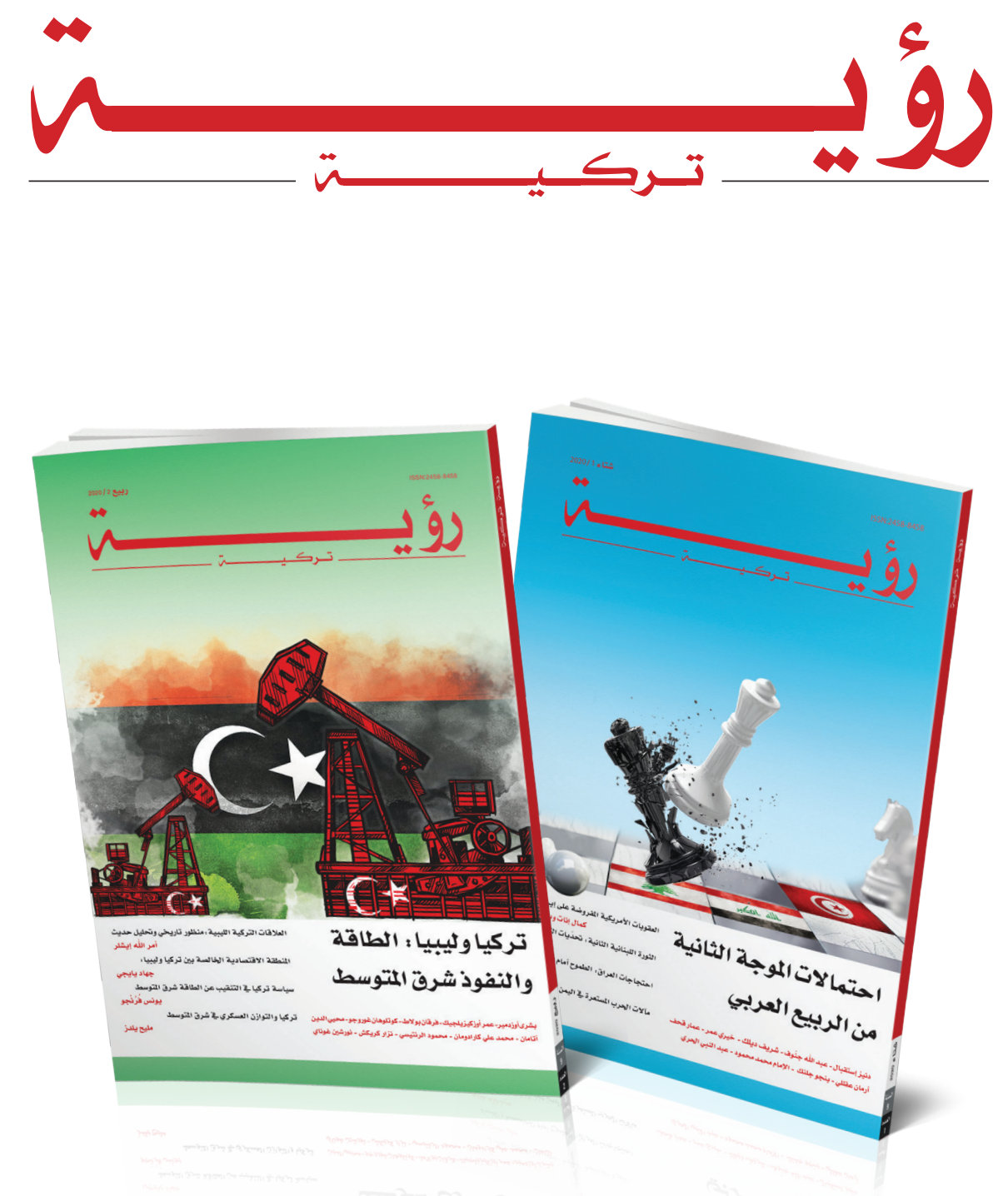

Rouya Turkiyyah is a quarterly academic journal published by SETA Foundation since 2012. It covers a broad range of topics related to domestic and foreign policy of the Middle Eastern countries focusing mostly in their politics, economy and social problems. Rouya Turkiyyah seeks to furnish a new regional perspective, through the allocation of new spaces for serious discussions on the World Affairs but more specifically in the Middle East affairs. 